\title{
Effect of Seed Rate and Row Spacing on Yield and Yield Components of Rain Fed Lowland Rice (Oryzasativa L.) Variety
}

\author{
Zelalem Tadesse*, Tilahun Tadesse, HabtamuAssega \\ Ethiopian Institute of Agricultural Research (EIAR), Fogera National Rice Research and Training Center \\ (FNRRiTC), P.O.Box 1937 Fogera, Ethiopia
}

*Corresponding Author: Zelalem Tadesse, Ethiopian Institute of Agricultural Research (EIAR), Fogera National Rice Research and Training Center (FNRRiTC), P.O.Box 1937 Fogera, Ethiopia

\begin{abstract}
An experiment was conducted at Fogera Plain during the rainy seasons of 2017 and 2018 to determine the effects of seed rate and row spacing on yield and yield component of rain fed lowland rice ecosystem. Four row spacing's (15, 20, 25and $30 \mathrm{~cm})$ and Seven seed rates (40, 60, 80, 100, 120,140 and160 $\mathrm{kg} / \mathrm{ha}$ ) were combined factorially and laid in $R C B$ Design with three replications.The objective of the experiment was to determine the effect of row spacing and seed rate on yield and yield components of rice in Fogera plain. All collected data were subjected to analysis of variance. Economic analysis was also done for grain yield. The results of the experiment showed that the main effect of seed rate was significantly affecting, panicle length, number of total and effective tillers per row meter length, grain yield, straw yield and harvest index whereas row spacing was significantly affected grain yield and number of total and effective tillers per row meter length. The interaction effect of seed rate and row spacing was significantly $(p<0.01)$ affected total tillers, number of effective tillers and grain yield. The highest grain yield $\left(3.25\right.$ tha $\left.^{-1}\right)$ was obtained at a seed rate of $120 \mathrm{kgha}^{-1}$ and $30 \mathrm{~cm}$ row spacing. The economic analysis indicated that a seed rate of $100 \mathrm{~kg} \mathrm{ha}^{-1}$ and row spacing of $20 \mathrm{~cm}$ is the most profitable treatment with mean net benefit of 50982.5.Birrha ${ }^{-1}$. Therefore it can be concluded that a seed rate of $100 \mathrm{~kg} / \mathrm{ha}$ and row spacing of $20 \mathrm{~cm}$ is preferable and recommended for rain fed lowland rice production ecosystem in Fogera plain.
\end{abstract}

Keywords: Low land rice, grain yield; row spacing; seeding rate. Economic analysis

\section{INTRODUCTION}

Rice (Oryza sativa L.), is one of the most important food crops and is considered as a major source of calories for more than half of the global population (Carrijo et al., 2017), covers $11 \%$ of total arable land (Khush, 2005). Rice has become a commodity of strategic significance across many African countries (Hegde and Hegde, 2013). It is also the most rapidly growing food sources across the continent due to the great urbanization in Africa more than any other region in the world.

Rice consumption is increasing faster than that of any other food staple in Africa at about $5.5 \%$ per year (2000-2010 average). This increase is driven by urbanization and related changes in eating habits, and population growth (Seck et al., 2012).Africa has sufficient land and water resource to produce enough rice to feed its own population and, in the long term, generate export revenues. Rice cultivars, rice-based cropping systems and the rice itself will, however, have to undergo adaptations and improvements in order to meet future demands for both food security of the growing population and environmental conservation (Asch and Brueck, 2010). Rice productivity in Africa is generally low about $1 \mathrm{t} \mathrm{ha}^{-1}$ in uplands, 1 to $2 \mathrm{tha}^{-1}$ in rain fed lowlands and 3 to $4 \mathrm{t} \mathrm{ha}^{-1}$ in the irrigated zones and a range of factor explains this low productivity (African Rice, 2010).

Ethiopia has a huge potential in both rain-fed and irrigated areas for rice production, which is, estimated about thirty million ha (MoARD, 2010; CSA, 2012) According to the National Rice Research and Development Strategy of Ethiopia, the trend in the number of rice producing farmers, area allocated and production showed high increase especially since 2006 (NRRDSE, 2009). Area rose from 6,000 hectares in 2005 to nearly 222,000 hectares in 2010 and paddy production from 15,460 tons to 887,400 tons, at the same time, the number of rice farmers increased from 18,000 to more than 565,000 (MoARD, 2010). At the Fogera plain, rice plays an important role in relaxing the problem of food-insecurity of the farming community. Besides, rice is among the target commodities 
that have received due emphasis in the promotion of agricultural production, and it is considered as the "millennium crop" expected to contribute to ensuring food security in Ethiopia. Although rice is introduced to the country very recently, it has proven to be a crop that can assure food security in Ethiopia, the second most populous nation in SSA (MoARD, 2010).

Optimum seeding rate and proper adjustment of row spacing are the most important production factors for higher grain yield. Spacing determines the number of plants per unit area (Yoshida et al., 1981). The plant toplant and row to row distance determines the plant population per unit area which has direct effect on yield. Closer spacing hampers intercultural operations, more competition arises among the plants for nutrient, air and light as a result plants become weaker and thinner and consequently, yield is reduced (Alam et al, 2012). Wider spacing also allows more competition among crop plants and weeds. As a result plant growth slows downand their grain yield decreases.

On the other hand, Closer spacing increases competition among plants for nutrients, air, light, which results in weaker plants, mutual shading thus favors more straw yield than grain yield (Sultana et al., 2012). Lower and higher plant densities have a positive influence on the yield of rice (Harris et al, 2015). High seeding rate leads to non-productive tillers, more severe disease pressure and susceptible to lodging (Garba et al, 2013).Optimum plant spacing ensures the plant to grow properly with their aerial and underground parts by utilizing more solar radiation and nutrients (Mohaddesi et al., 2011).

There are a number of agronomic management constrains with this crop. Rice is becoming a high potential crop and there is a lack of appropriate agronomic management recommendations that could help to maximize the productivity of the cultivation techniques in the study area. Among the rice production constrains seed rate and row spacing is an important factor Fogera Plain. Area specific recommendation of seed rate is vital to set optimum seed rate and row spacing for rice production in the study area. Therefore the objective of the present study is to determine the effect of row spacing and seed rate on yield and yield components of rice in Fogera plain.

\section{MATERIALS AND MeTHOdS}

\subsection{Site Description}

The experimental site is located at $11^{0} 49^{\prime} 55$ North latitude and $37^{0} 37^{\prime} 40$ East longitudes. The altitude of the experimental site is 1815 meters above sea level. The average mean annual minimum and maximum temperature is $12.75{ }^{\circ} \mathrm{C}$ and $27.37{ }^{\circ} \mathrm{C}$, respectively. The main rainfall is in July and August (Fig. 1). The experiment was conducted from 2017 to 2018.

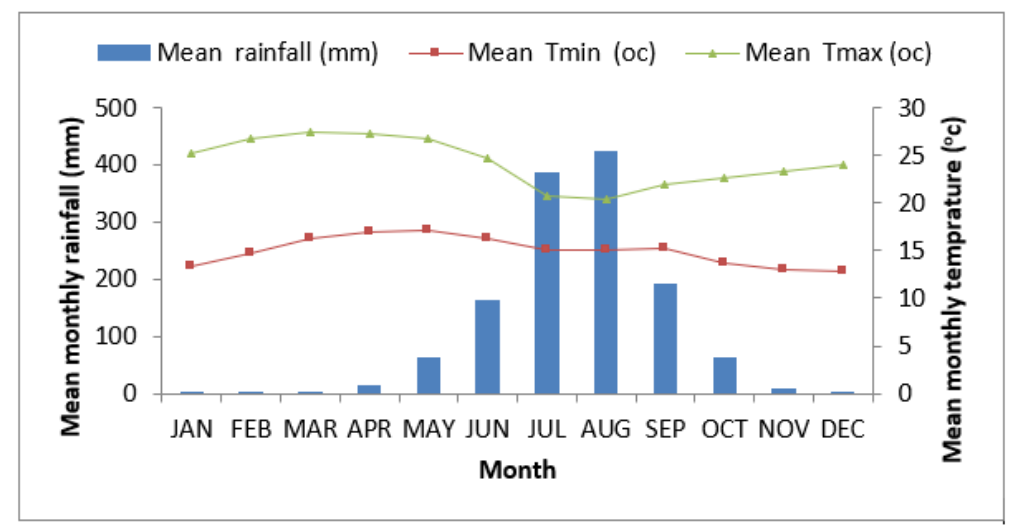

Figure1. The Average rainfall and temperature condition of Fogera plain for the period of 1981-2017.

\subsection{Treatments, Design and Management}

The treatments consists a factorial combination of four levels of row spacings $(15,20,25 \mathrm{and} 30 \mathrm{~cm})$ and seven levels of seed rates $\left(40,60,80,100,120,140\right.$ and160 $\left.\mathrm{kgha}^{-1}\right)$ in randomized complete block design with three replications. The gross plot size was $3 \mathrm{~m} * 4 \mathrm{~m}$. The net plot was made by excluding the left and right two outer rows and a plot length of $0.5 \mathrm{~m}$ from the top and bottom sides of the plot area. Thus the net plot size for the respective row spacings $(15,20,25$ and $30 \mathrm{~cm})$ were $3 \mathrm{~m} * 2.4 \mathrm{~m}$; $3 \mathrm{~m} * 2.2 \mathrm{~m}, 3 \mathrm{~m} * 2 \mathrm{~m}$ and $3 \mathrm{~m} * 1.8 \mathrm{~m}$. The variety Edget was used for this experiment. Recommended fertilizer rates of $69 / 23 \mathrm{~kg} \mathrm{~N} / \mathrm{P}_{2} \mathrm{O}_{5}$ ha $^{-1}$ was used in the experiment (Tilahun et al., 2007). 


\subsection{Data Collected}

Data's such as plant height $(\mathrm{cm})$, Panicle length $(\mathrm{cm})$, number of total tillers/row meter length, number of effective tillers/row meter length,, thousand seeds weight, grain yield, straw yield and harvest index were recorded from the net plot.

\subsection{Statistical Data Analyses}

All collected data were subjected to analysis of variance (ANOVA) using SAS software version 9.2 (SAS-Institute, 2008). Combined analysis over locations and years was performed. Between treatments, comparisons of means were made using the Least Significant Difference (LSD) test at 1 and 5\% probability levels. The mean grain and straw yield data was adjusted by $90 \%$ and economic analysis was carried out by following CIMMYT (1988) procedures by taking all variable costs. The prevailing cost of inputs and out puts in year 2019 considered for the analysis. The cost of rice grain and straw were Birr 13.5 and $1.2 / \mathrm{kg}$, respectively. Total costs that varied ( seed and planting cost) for each treatments was calculated and treatments were ranked in order of ascending total variable cost (TVC) and dominance analysis was used to eliminate those treatments costing more but producing a lower net benefit than the next lowest cost treatment. The prices of the inputs that were prevailing at the time of their use were considered for working out the cost of cultivation. Net returns per hectare were calculated by deducting cost of production per hectare from gross income per hectare. A treatment which is non-dominated and having the highest net benefit is said to be economically profitable (CIMMYT, 1988).

\section{RESULTS AND DISCUSSION}

The analysis of variance exhibited that seed rate had significantly $(\mathrm{P}<0.05)$ influenced panicle length. Whereas, row spacing and interaction effect did not show significant effect on panicle length.(Table 1).The highest panicle length (18.6) was observed at a seed rate of $40 \mathrm{kgha}^{-1}$ and the lowest panicle length (17.1 and 17.2) recorded from 160 and $140 \mathrm{~kg} \mathrm{ha}^{-1}$ seed rate respectively (Table 2). At the lower seed rate of $40 \mathrm{~kg} \mathrm{ha}^{1}{ }^{1}$, the panicle length was higher compared to higher seed rate of 140 and $160 \mathrm{~kg} \mathrm{ha-}{ }^{1}$. This might be due to more free space between plants at the lower seed rate and less intraplant competition for available resources that resulted in higher panicle length. This result is in line with the finding of ZewdieBishaw et al. (2014) who reported that plant height and panicle length are negatively interrelated on wheat. Shorter plant produce longer panicle length and longer plant produce shorter panicle and higher biomass production. Gafaar (2007) also stated that increasing sowing density from 200 up to 400 grains $\mathrm{m}^{-2}$ significantly decreased spike length. Similarly, Seleiman et al. (2010) reported that the longest spikes were obtained from 250 and 300 grains per $\mathrm{m}^{2}$ but without significant differences between both of them.

The analysis of variance indicated that the main effects of seed rate and row spacing highly significantly $(\mathrm{p}<0.01)$ affected both number of total and effective tillers per row length. Moreover, the interaction of seed rate and row spacing also highly significant $(\mathrm{P}<0.01)$ (Table1) The maximum number of total tillers per row meter length (66.5) and the minimum (56.3) were recorded from the seed rate of $140 \mathrm{~kg} \mathrm{ha}-{ }^{1}$ and $60 \mathrm{~kg} \mathrm{ha-}{ }^{-}$, respectively (Table 2 ). In regard to the row spacingmore number of total tillers per row meter length $(65.5)$ was recorded from $(30 \mathrm{~cm})$ row spacing .On the other hand, smallest number of total tillers per row meter length (54.8) was observed from $15 \mathrm{~cm}$ row spacing. With regard to the interaction effect, the maximum number of total tillers (75.85) was obtained at $120 \mathrm{kgha}^{-1}$ seeds rate and a row spacing of $30 \mathrm{~cm}$ (Table 3 ).

The analysis of variance indicated that the main effects of seed rate and row spacing highly significantly $(\mathrm{p}<0.01)$ affected number of effective tillers per row meter length (Table 1). However, the interaction effect of seed rate and row spacing also had highly significant $(p<0.01)$ effect on number of effective tillers per row meter length. The highest number of effective tillers per row meter length (64.96) was observed at seed rate of $140 \mathrm{~kg} \mathrm{a}^{1}{ }^{1}$ while the lowest number of effective tillers per $1 \mathrm{~m}$ row length (55.28 and 54.95) observed at seeding rate of 40 and $60 \mathrm{~kg}$ ha- ${ }^{1}$ respectively and statistically similar. In addition to this the highest number of effective tillers (63.79) per row meter length was recorded at row spacing of $30 \mathrm{~cm}$ while, the minimum number of effective tillers (53.73) per row meter length was recorded at row spacing of $15 \mathrm{~cm}$ (Table 2).

Wider spacing produced higher tillers per hill than closer spacing. The production of more tillers in widely spaced plants was probably due to absorption of more nutrients and moisture and also to the 
availability of more sunlight in comparison to densely plants. Similar results were reported by (Haque, 2002).This result was also in agreement with (SewunetAshebir, 2005 ) reported the highest effective tillers were recorded at medium spacing performed better as compared to lower spacing. (Yamada, 1961) also showed that under dense planting, the growth of each plant decreases and the size of the plants and productive tillers become smaller. The more densely the rice plants, fewer are the number of stems or tillers and productive tillers per hill but their number increases per unit area.

Analysis of variance showed that the main effect of seed rate and row spacing had highly significant effect $(\mathrm{P}<0.01)$ on grain yield. On the hand seed rate affected significantly $(\mathrm{P}<0.01)$ straw yield (Table 1). However, the interaction effect of seeding rate and row spacing showed highly significant $(\mathrm{p}<0.01)$ effect on grain yield but not in straw yield (Table 1). The highest grain yield $\left(3.45 \mathrm{tha}^{-1}\right)$ was obtained at the seed rate of $100 \mathrm{~kg} \mathrm{ha}-{ }^{1}$ and the lowest grain yield $\left(3.1 \mathrm{t} / \mathrm{ha}^{-}\right)$was obtained at seed rate of $160 \mathrm{~kg} / \mathrm{ha}$ (Table 2). The row spacing of $25 \mathrm{~cm}$ produced maximum grain yield $\left(3.31 \mathrm{t} / \mathrm{ha}^{-}{ }^{1}\right)$ followed by 30 and $20 \mathrm{~cm}\left(3.2\right.$ and $\left.3.1 \mathrm{t} / \mathrm{ha}^{1}\right)$ respectively and the lowest grain yield $(3.12 \mathrm{t} / \mathrm{ha})$ was observed at a row spacing of $15 \mathrm{~cm}$. From the above result it could be suggested that as seeding rate increased there was no significant and proportional yield increment observed. Likewise, grain yield of rice, was significantly affected at optimum seed rate but further increase in seed rate did not increase the yield. (Balocket al., 2002) who reported that the increased plant spacing considerably resulted in vigorous plant growth and caused a significant increase in number of panicles per hill, grain yield per hill, filled grain per panicle and thousand grain weights. Furthermore, other workers (Mosalemet al., 2000) reported that increasing seeding rates decreased the number of spikelets/panicle, spike length, number and weight of grains/spike in wheat. Grain yield of rice increased with the increase in the number of plants per unit area as long as there is space in the cultivated areas. When planting density exceeds optimum level, competition among plants for light above ground and for nutrients below ground becomes severe. Consequently, plant growth slow and grain yield decreases. Zeng and Shannon (2000) reported that the reduction in fertility at high density was one of the causes for the reduction of seed yield per plant with the increase of seeding density.

The main effect of seed rate highly significantly $(\mathrm{P}<0.01)$ affected straw yield whereas the main effect of row spacing and its interaction effect didn't show significant ( $p>0.05)$ effect on straw yield (Table 1). The highest straw yield (6.51 and 5.96 tha $\left.^{-1}\right)$ was observed at seed rate of $100 \mathrm{kgha}^{-}{ }^{1}$ and $160 \mathrm{~kg} \mathrm{ha}^{-1}$ which is statistically similar. While the lowest straw yield $\left(4.75 \mathrm{t} \mathrm{ha}^{-1}\right)$ was found with a seed rate of $40 \mathrm{~kg} \mathrm{ha}^{-1}$ (Table 2). There was a linear increase in straw yield as the seeding rate was increased. However, it was statistically in parity with in straw yield obtained in response to the seeding rate of 60,80 and $140 \mathrm{~kg} \mathrm{ha}^{-1}$. The lowest spacing might have influenced vegetative growth in terms of plant height and number of tillers per hill (effective and non-effective tillers) which resulted in increased straw yield. Sultana et al. (2012) also reported a similar results and the higher straw yield was obtained in $20 \mathrm{~cm}$ row spacing in rice.

Harvest index represents the ratio of grain yield to the total above ground dry matter production (Marschener, 1995). The present results showed that harvest index was highly significantly $(\mathrm{p}<0.01)$ affected by seed rate but not by row spacing and its interaction effect (Table 1). The highest harvest index $(38.68 \%)$ was recorded at a seed rate of $40 \mathrm{~kg}$ ha- ${ }^{1}$ while lowest harvest index $(35.1 \%)$ was recorded at the seeding rate of $100 \mathrm{~kg} \mathrm{ha}^{-1}$ respectively, (Table 2). The ability of a cultivar to convert the dry matter into economic yield is indicated by its harvest index. The higher the harvest index value, the greater the physiological potential of the crop for converting the dry matter to grain yield. One of the ways to increase the yield is to increase harvest index. Sink formation and ripening are the two physiological processes that explain the improvement in HI (Akita, 1982).Based on the principles of economic analysis CIMMYT (1988), the minimum acceptable marginal rate of return (MRR \%) should be $100 \%$. The economic analysis was done on the basis of the prevailing prices of variable costs using the Ethiopian currency (Birr). Grain and straw yields adjustments, calculations of total variable costs (TVC), gross benefits (GB) and net benefits (NB) were performed (Table 4). Dominance analysis was performed after arranging the treatments in their order of TVC. Treatments are considered as dominated if it has higher TVC but lower NB than a previous treatment with lower TVC and higher NB (Table 5). Non dominated treatments were taken out and marginal rate of return (MRR) was computed (Table 6). Highest NB (Birr 50982.5 ha ${ }^{-1}$ ) with acceptable level of MRR (913.01) was observed at a row spacing of $20 \mathrm{~cm}$ and $100 \mathrm{~kg}^{2}$ seed rate ha ${ }^{-1}$ (Table 6). The combined application of a seed rate of $100 \mathrm{kgha}^{-1}$ and $20 \mathrm{~cm}$ row spacing is the most profitable rate to be recommended for rice production in Fogera plain. 
Effect of Seed Rate and Row Spacing on Yield and Yield Components of Rain Fed Lowland Rice (Oryzasativa L.) Variety

\section{SuMmary AND RECOMMENDATION}

Treatments had a significant effect on yield and yield components of rice. Among the treatments, drilling $100 \mathrm{~kg}$ ha- ${ }^{1}$ seed rate and a row spacing of $25 \mathrm{~cm}$ produced maximum grain yield $\left(3.3 \mathrm{t} / \mathrm{ha}^{-1}\right)$ than other treatments. Partial budget analysis also revealed that highest NB (Birr 50982.5 ha ${ }^{-1}$ ) with acceptable level of MRR (913.01) was observed at a row spacing of $20 \mathrm{~cm}$ and $100 \mathrm{~kg}$ seed rate ha ${ }^{-1}$. Therefore the combined application of a seed rate of $100 \mathrm{kgha}^{-1}$ and $20 \mathrm{~cm}$ row spacing is the most profitable rate to be recommended for rice production in Fogera plain and other similar agroecologies.

Table1. Analysis of variance (ANOVA) for Panicle length, Total tillers, Number of effective tillers, Grain Yield, Straw Yield and Harvest Index of seed rate and row spacing of low land rice

\begin{tabular}{|c|c|c|c|c|c|c|c|c|c|c|}
\hline $\begin{array}{c}\text { Sources of } \\
\text { variation }\end{array}$ & DF & $\begin{array}{c}\text { Plant } \\
\text { height } \\
(\mathrm{cm})\end{array}$ & $\begin{array}{c}\text { Panicle } \\
\text { length } \\
(\mathrm{cm})\end{array}$ & $\begin{array}{c}\text { Total } \\
\text { tillers/m } \\
\text { row }\end{array}$ & $\begin{array}{l}\text { Number } \\
\text { of } \\
\text { Effective } \\
\text { tillers/ } \mathbf{m} \\
\text { row }\end{array}$ & $\begin{array}{c}\text { No. of } \\
\text { fertile } \\
\text { spikes/pa } \\
\text { nicle }\end{array}$ & $\begin{array}{l}\text { Grain } \\
\text { Yield } \\
\text { (t/ha) }\end{array}$ & 1000 sw/g & $\begin{array}{l}\text { Straw } \\
\text { Yield } \\
(\mathrm{t} / \mathrm{ha})\end{array}$ & HI (\%) \\
\hline Loca & 6 & $\begin{array}{l}2199 \\
087\end{array}$ & $\begin{array}{r}207.0 \\
70\end{array}$ & $\begin{array}{r}1116 \\
794\end{array}$ & $\begin{array}{c}12275.75 \\
459 * *\end{array}$ & $\begin{array}{c}249.9839 \\
25 * *\end{array}$ & $\begin{array}{c}42.32640 \\
57 * *\end{array}$ & $\begin{array}{c}923.7156 \\
07 * *\end{array}$ & $\begin{array}{c}150.6996 \\
278 * *\end{array}$ & 39 \\
\hline RS_cm & 3 & $\begin{array}{c}90.0074 \\
\text { NS }\end{array}$ & $\begin{array}{c}7.922211 \\
\text { NS }\end{array}$ & $\begin{array}{c}2757.402 \\
61 * *\end{array}$ & $\begin{array}{c}2434.770 \\
69 * *\end{array}$ & $\begin{array}{c}21.42713 \\
8 \mathrm{NS}\end{array}$ & $\begin{array}{c}0.909444 \\
7 *\end{array}$ & $\begin{array}{c}0.884915 \\
\text { NS }\end{array}$ & $\begin{array}{c}3.049854 \\
5 \mathrm{NS}\end{array}$ & $\begin{array}{c}18.49852 \\
9 \mathrm{NS}\end{array}$ \\
\hline Rep & 2 & $\begin{array}{c}109.896 \\
85 \mathrm{NS} \\
\end{array}$ & $\begin{array}{c}48.66702 \\
9 * * \\
\end{array}$ & \begin{tabular}{|c|}
172.8489 \\
$5 \mathrm{NS}$ \\
\end{tabular} & $\begin{array}{c}295.7069 \\
7 \mathrm{NS} \\
\end{array}$ & $\begin{array}{c}37.20774 \\
\text { 3NS }\end{array}$ & $\begin{array}{c}3.044433 \\
4 * *\end{array}$ & $\begin{array}{c}15.95158 \\
0 *\end{array}$ & $\begin{array}{c}13.31233 \\
20 * * \\
\end{array}$ & $\begin{array}{c}34.73053 \\
5 \mathrm{NS} \\
\end{array}$ \\
\hline & 6 & \begin{tabular}{|c|}
383.723 \\
$17 \mathrm{NS}$ \\
\end{tabular} & $\begin{array}{c}23.86534 \\
6 * *\end{array}$ & $\begin{array}{c}1130.663 \\
47 * *\end{array}$ & $\begin{array}{c}1085.356 \\
17 * * \\
\end{array}$ & $\begin{array}{c}16.33039 \\
2 \mathrm{NS} \\
\end{array}$ & $\begin{array}{c}2.574744 \\
4 * *\end{array}$ & $\begin{array}{c}0.509947 \\
\text { NS }\end{array}$ & $\begin{array}{c}24.51515 \\
43 * *\end{array}$ & $\begin{array}{r}104 . \\
18 \\
\end{array}$ \\
\hline $\begin{array}{c}\text { Location*RS_c } \\
\mathrm{m}\end{array}$ & 18 & $\begin{array}{c}27.5877 \\
5 \mathrm{NS} \\
\end{array}$ & $\begin{array}{c}2.050647 \\
\text { NS }\end{array}$ & $\begin{array}{c}114.9918 \\
9 \mathrm{NS}\end{array}$ & $\begin{array}{c}124.2040 \\
4 \mathrm{NS}\end{array}$ & $\begin{array}{c}15.55381 \\
9 \mathrm{NS}\end{array}$ & $\begin{array}{c}0.521189 \\
6^{*}\end{array}$ & $\begin{array}{c}4.878561 \\
\text { NS }\end{array}$ & $\begin{array}{c}2.044944 \\
8 \mathrm{NS}\end{array}$ & $\begin{array}{c}43.40834 \\
4 \mathrm{NS}\end{array}$ \\
\hline Location*Rep & 12 & $\begin{array}{c}198.122 \\
07 \mathrm{NS}\end{array}$ & $\begin{array}{c}22.35633 \\
2 * *\end{array}$ & $\begin{array}{c}85.56525 \\
\text { NS }\end{array}$ & $\begin{array}{c}82.23709 \\
\text { NS }\end{array}$ & $\begin{array}{c}20.20194 \\
9 \mathrm{NS}\end{array}$ & $\begin{array}{c}0.495090 \\
7 \mathrm{NS}\end{array}$ & $\begin{array}{c}4.538268 \\
\text { NS }\end{array}$ & $\begin{array}{c}3.589544 \\
0 *\end{array}$ & $\begin{array}{c}29.40430 \\
3 \mathrm{NS}\end{array}$ \\
\hline $\begin{array}{c}\text { Location*SR_k } \\
\mathrm{g}\end{array}$ & 36 & $\begin{array}{c}47.5344 \\
9 \mathrm{NS}\end{array}$ & $\begin{array}{c}3.014579 \\
\mathrm{NS}\end{array}$ & $\begin{array}{c}196.6996 \\
4 *\end{array}$ & $\begin{array}{c}189.2109 \\
7 *\end{array}$ & $\begin{array}{c}21.74697 \\
\text { 0NS }\end{array}$ & $\begin{array}{c}0.496931 \\
0^{*}\end{array}$ & $\begin{array}{c}9.032433 \\
* *\end{array}$ & $\begin{array}{c}2.552952 \\
8 \mathrm{NS}\end{array}$ & $\begin{array}{c}36.08437 \\
3 \mathrm{NS}\end{array}$ \\
\hline Rep*RS_cm & 6 & $\begin{array}{c}10.5921 \\
7 \mathrm{NS} \\
\end{array}$ & $\begin{array}{c}2.063982 \\
\text { NS }\end{array}$ & $\begin{array}{c}56.73911 \\
\text { NS }\end{array}$ & $\begin{array}{c}27.45025 \\
\text { NS }\end{array}$ & $\begin{array}{c}3.241493 \\
\text { NS }\end{array}$ & $\begin{array}{c}0.313630 \\
6 \mathrm{NS}\end{array}$ & $\begin{array}{c}2.577858 \\
\mathrm{NS}\end{array}$ & $\begin{array}{c}0.670167 \\
4 N S\end{array}$ & $\begin{array}{l}7144 \\
\text { JS }\end{array}$ \\
\hline $\mathrm{RS} \_\mathrm{cm} \_* \mathrm{SR} \_\mathrm{kg}$ & 18 & $\begin{array}{c}48.2529 \\
6 \mathrm{NS} \\
\end{array}$ & $\begin{array}{c}3.395149 \\
\mathrm{NS}\end{array}$ & $\begin{array}{c}542.7148 \\
7 * * \\
\end{array}$ & $\begin{array}{c}519.4935 \\
4 * * \\
\end{array}$ & $\begin{array}{c}14.37410 \\
3 \mathrm{NS} \\
\end{array}$ & $\begin{array}{c}0.823147 \\
1 * *\end{array}$ & $\begin{array}{c}5.956512 \\
\text { NS }\end{array}$ & $\begin{array}{c}2.568008 \\
4 \mathrm{NS} \\
\end{array}$ & $\begin{array}{c}37.90270 \\
6 \mathrm{NS} \\
\end{array}$ \\
\hline Rep*SR_kg & 12 & \begin{tabular}{|c}
5.67498 \\
NS
\end{tabular} & $\begin{array}{c}1.477806 \\
\text { NS }\end{array}$ & $\begin{array}{c}179.8634 \\
9 \mathrm{NS}\end{array}$ & $\begin{array}{c}171.2209 \\
5 \mathrm{NS}\end{array}$ & $\begin{array}{c}29.09967 \\
\text { 4NS }\end{array}$ & $\begin{array}{c}0.599186 \\
0 *\end{array}$ & $\begin{array}{c}6.926008 \\
\text { NS }\end{array}$ & $\begin{array}{c}2.067582 \\
\text { 2NS }\end{array}$ & $\begin{array}{c}32.00896 \\
8 \mathrm{NS}\end{array}$ \\
\hline $\begin{array}{c}\text { Location*Rep* } \\
\text { RS_cm }\end{array}$ & 36 & \begin{tabular}{|c}
30.3354 \\
$3 \mathrm{NS}$ \\
\end{tabular} & $\begin{array}{c}2.094019 \\
\mathrm{NS}\end{array}$ & $\begin{array}{c}87.05057 \\
\text { NS }\end{array}$ & $\begin{array}{c}96.08728 \\
\text { NS }\end{array}$ & $\begin{array}{c}20.54865 \\
\text { 2NS }\end{array}$ & $\begin{array}{c}0.366311 \\
9 \mathrm{~ns}\end{array}$ & $\begin{array}{c}5.617603 \\
\mathrm{NS}\end{array}$ & $\begin{array}{c}2.181365 \\
8 \mathrm{NS}\end{array}$ & $\begin{array}{c}21.62839 \\
5 \mathrm{NS} \\
\end{array}$ \\
\hline $\begin{array}{c}\text { Locatio*RS_cm } \\
* \text { *SR_kg }\end{array}$ & 108 & $\begin{array}{c}19.6924 \\
5 \mathrm{NS}\end{array}$ & $\begin{array}{c}2.590732 \\
\text { NS }\end{array}$ & $\begin{array}{c}129.1982 \\
9 \mathrm{NS}\end{array}$ & $\begin{array}{c}129.1334 \\
2 \mathrm{NS}\end{array}$ & $\begin{array}{c}14.18089 \\
9 \mathrm{NS}\end{array}$ & $\begin{array}{c}0.495713 \\
3 * *\end{array}$ & $\begin{array}{c}5.374410 \\
\text { NS }\end{array}$ & $\begin{array}{c}2.744089 \\
1 * *\end{array}$ & $\begin{array}{c}33.91027 \\
4 \mathrm{NS}\end{array}$ \\
\hline $\begin{array}{c}\text { Location*Rep* } \\
\text { SR_kg } \\
\end{array}$ & 72 & $\begin{array}{c}20.3109 \\
0 \mathrm{NS}\end{array}$ & $\begin{array}{c}1.847621 \\
\mathrm{NS}\end{array}$ & $\begin{array}{c}83.06587 \\
\text { NS }\end{array}$ & $\begin{array}{c}80.32154 \\
\text { NS }\end{array}$ & $\begin{array}{c}15.68081 \\
\text { ONS }\end{array}$ & $\begin{array}{c}0.213280 \\
7 \mathrm{~ns}\end{array}$ & $\begin{array}{c}4.892966 \\
\text { NS }\end{array}$ & $\begin{array}{c}1.818553 \\
\text { 4NS }\end{array}$ & $\begin{array}{c}31.13984 \\
9 \mathrm{NS}\end{array}$ \\
\hline $\begin{array}{c}\text { Rep*RS_cm_*S } \\
\text { R_kg } \\
\end{array}$ & 36 & \begin{tabular}{|c|}
37.1982 \\
$7 \mathrm{NS}^{\prime}$
\end{tabular} & $\begin{array}{c}4.155389 \\
\text { NS }\end{array}$ & $\begin{array}{c}90.77742 \\
\mathrm{NS}\end{array}$ & $\begin{array}{c}99.06439 \\
\text { NS }\end{array}$ & $\begin{array}{c}15.48970 \\
6 \mathrm{NS}\end{array}$ & $\begin{array}{c}0.500802 \\
3 *\end{array}$ & $\begin{array}{c}4.457263 \\
\text { NS }\end{array}$ & $\begin{array}{c}2.250980 \\
9 \mathrm{NS}\end{array}$ & $\begin{array}{c}24.97417 \\
4\end{array}$ \\
\hline Error & 216 & $\begin{array}{c}26.8106 \\
2\end{array}$ & 2.851737 & 121.9432 & 116.7209 & 374.7861 & $\begin{array}{c}0.309259 \\
8\end{array}$ & 5.036729 & 1.815973 & 30.38443 \\
\hline $\mathrm{CV} \%$ & & 6.71 & 9.55 & 18.26 & 18.33 & 24.31 & 17.23 & 6.93 & 23.59 & 15.02 \\
\hline
\end{tabular}

$P L=$ Panicle length, TT/RML, Number of Total tillers/row meter length, NET/RML=number of effective tillers Irow meter length, GY (ton) grain yield ton /ha, SY (ton) straw yield ton /ha and HI (\%) harvest index.

Table2. Main effects of seed rate and row spacing on yield and yield components of low land rice

\begin{tabular}{|c|c|c|c|c|c|c|}
\hline Seed rate $\left(\mathrm{kgha}^{-1}\right)$ & PL (cm) & TT/RML & NET/RML & GY $\left(\right.$ tonha $\left.^{-1}\right)$ & SY $\left(\right.$ tonha $^{-1}$ & HI (\%) \\
\hline 40 & $18.6195 \mathrm{~A}$ & $56.619 \mathrm{D}$ & $54.952 \mathrm{D}$ & $2.89050 \mathrm{D}$ & $4.7512 \mathrm{D}$ & $38.6831 \mathrm{~A}$ \\
\hline 60 & $18.0133 \mathrm{~B}$ & $56.369 \mathrm{D}$ & $55.286 \mathrm{D}$ & $3.24097 \mathrm{BC}$ & $5.4290 \mathrm{C}$ & $36.8615 \mathrm{AB}$ \\
\hline 80 & $17.9026 \mathrm{BC}$ & 58.571CD & 56.845CD & $3.25961 \mathrm{BC}$ & $5.6222 \mathrm{BC}$ & $37.0289 \mathrm{AB}$ \\
\hline 100 & 17.5579BCD & $62.262 \mathrm{~B}$ & 60.762B & $3.45280 \mathrm{~A}$ & $6.5158 \mathrm{~A}$ & $35.1723 \mathrm{~B}$ \\
\hline 120 & $17.3793 \mathrm{CD}$ & $62.607 \mathrm{~B}$ & $60.798 \mathrm{~B}$ & $3.31124 \mathrm{~B}$ & 5.8944B & $35.9450 \mathrm{~B}$ \\
\hline 140 & $17.1824 \mathrm{D}$ & $66.548 \mathrm{~A}$ & $64.964 \mathrm{~A}$ & $3.25198 \mathrm{BC}$ & $5.8179 \mathrm{BC}$ & $37.0223 \mathrm{AB}$ \\
\hline
\end{tabular}


Effect of Seed Rate and Row Spacing on Yield and Yield Components of Rain Fed Lowland Rice (Oryzasativa L.) Variety

\begin{tabular}{|c|c|c|c|c|c|c|}
\hline $\mathbf{1 6 0}$ & $17.1250 \mathrm{D}$ & $60.238 \mathrm{BC}$ & $58.857 \mathrm{BC}$ & $3.10017 \mathrm{C}$ & $5.9638 \mathrm{~A}$ & $36.1051 \mathrm{~B}$ \\
\hline $\begin{array}{c}\text { Row Spacing } \\
(\mathbf{c m})\end{array}$ & & & & & & \\
\hline $\mathbf{1 5}$ & 17.5376 & $54.850 \mathrm{C}$ & $53.735 \mathrm{C}$ & $3.12488 \mathrm{~B}$ & 5.5423 & 36.8460 \\
\hline $\mathbf{2 0}$ & 17.4366 & $60.231 \mathrm{~B}$ & $58.476 \mathrm{~B}$ & $3.22968 \mathrm{AB}$ & 5.8631 & 36.2114 \\
\hline $\mathbf{2 5}$ & 17.8337 & $61.197 \mathrm{~B}$ & $59.687 \mathrm{~B}$ & $3.31715 \mathrm{~A}$ & 5.8147 & 37.0476 \\
\hline $\mathbf{3 0}$ & 17.9235 & $65.558 \mathrm{~A}$ & $63.796 \mathrm{~A}$ & $3.18960 \mathrm{AB}$ & 5.6339 & 36.6483 \\
\hline
\end{tabular}

$P L=$ Panicle length, TT/RML = Number of Total tillers/row meter length, NET/RML=number of effective tillers Irow meter length, GY= grain yield ton ha-1, SY= straw yield ton ha ${ }^{-1}$ and $H I(\%)=$ harvest index.

Table3. Interaction effect of seed rate by row spacing on yield and yield components of lowland rice at Fogera.

\begin{tabular}{|c|c|c|c|c|c|c|}
\hline TRT & Row space & Seed Rate & TTN/RML & NNET/ RML & GY $\left(\right.$ tha $\left.^{-1}\right)$ & SY $\left(\right.$ tha $\left.^{-1}\right)$ \\
\hline 1 & 15 & 40 & 53.381HIJ & $51.952 \mathrm{HIJ}$ & 2.9043IJKL & 4.7247 \\
\hline 2 & 15 & 60 & 53.524HIJ & $52.571 \mathrm{GHIJ}$ & 3.0649FGHIJKL & 5.3416 \\
\hline 3 & 15 & 80 & $52.762 \mathrm{~J}$ & $51.571 \mathrm{IJ}$ & 3.3315BCDEFGH & 6.0545 \\
\hline 4 & 15 & 100 & $52.381 \mathrm{~J}$ & $51.238 \mathrm{~J}$ & 3.2075CDEFGHIJKL & 5.7321 \\
\hline 5 & 15 & 120 & 55.476FGHIJ & 54.333GHIJ & 3.0654FGHIJKL & 5.5386 \\
\hline 6 & 15 & 140 & 56.762FGHIJ & 56.048GHIJ & 3.3482BCDEFG & 5.4599 \\
\hline 7 & 15 & 160 & 59.667EFGHIJ & 58.429DEFGHIJ & $2.9523 \mathrm{GHIJKL}$ & 5.9445 \\
\hline 8 & 20 & 40 & 53.619HIJ & $51.667 \mathrm{IJ}$ & $2.8268 \mathrm{~L}$ & 4.6429 \\
\hline 9 & 20 & 60 & $53.333 \mathrm{IJ}$ & $51.095 \mathrm{~J}$ & 3.1543CDEFGHIJKL & 5.6952 \\
\hline 10 & 20 & 80 & 57.048FGHIJ & $55.476 \mathrm{GHIJ}$ & 3.0582FGHIJKL & 5.6579 \\
\hline 11 & 20 & 100 & $70.000 \mathrm{ABC}$ & 69.000ABC & $3.7705 \mathrm{~L}$ & 7.1490 \\
\hline 12 & 20 & 120 & 57.952EFGHIJ & 55.714GHIJ & 3.1371DEFGHIJKL & 5.9444 \\
\hline 13 & 20 & 140 & $70.952 \mathrm{ABC}$ & $68.762 \mathrm{ABC}$ & 3.2904CDEFGHIJ & 6.1108 \\
\hline 14 & 20 & 160 & 58.714EFGHIJ & 57.619EFGHIJ & 3.3703BCDEF & 5.8417 \\
\hline 15 & 25 & 40 & 62.000DEF & 60.190DEFG & 2.9374HIJKL & 4.7961 \\
\hline 16 & 25 & 60 & 59.000EFGHIJ & 57.048FGHIJ & $2.8782 \mathrm{KL}$ & 4.9622 \\
\hline 17 & 25 & 80 & 54.000GHIJ & 54.333GHIJ & $3.5205 \mathrm{ABCD}$ & 5.7009 \\
\hline 18 & 25 & 100 & 59.286EFGHIJ & 57.857EFGHIJ & $3.6355 \mathrm{AB}$ & 6.7918 \\
\hline 19 & 25 & 120 & 61.143DEFGH & 59.333DEFGH & $3.5464 \mathrm{ABC}$ & 6.3497 \\
\hline 20 & 25 & 140 & 65.524CDE & 63.667CDEF & 3.2242CDEFGHIJKL & 5.7718 \\
\hline 21 & 25 & 160 & 67.429BCD & $65.381 \mathrm{BCD}$ & $3.4780 \mathrm{ABCDE}$ & 6.3302 \\
\hline 22 & 30 & 40 & 65.286CDE & 63.571CDEF & $2.8935 \mathrm{JKL}$ & 4.8410 \\
\hline 23 & 30 & 60 & 60.619DEFGHI & 59.095DEFGHI & 3.3033BCDEFGHI & 5.7171 \\
\hline 24 & 30 & 80 & 61.667DEFG & 59.762DEFG & 3.1283DEFGHIJKL & 5.8584 \\
\hline 25 & 30 & 100 & $67.381 \mathrm{BCD}$ & 64.952BCDE & 3.1977CDEFGHIJKL & 6.3903 \\
\hline 26 & 30 & 120 & $75.857 \mathrm{~A}$ & $73.810 \mathrm{~A}$ & 3.2589BCDEFGHIJK & 5.7451 \\
\hline 27 & 30 & 140 & $72.952 \mathrm{AB}$ & $71.381 \mathrm{AB}$ & 3.1011EFGHIJKL & 5.1464 \\
\hline 28 & 30 & 160 & 55.143FGHIJ & $54.000 \mathrm{GHIJ}$ & 3.4444ABCDEF & 5.7386 \\
\hline $\mathbf{C V}$ & & & 18.26 & 18.33 & 17.23 & - \\
\hline
\end{tabular}

Table4. Economic analysis for grain and straw yield for seed rate by row spacing interaction of low land rice at Fogera

\begin{tabular}{|c|c|c|c|c|c|c|c|c|c|}
\hline $\begin{array}{c}\text { Treat } \\
\text { ments }\end{array}$ & $\mathbf{R S}$ & $\mathbf{S R}$ & $\begin{array}{c}\mathbf{G Y} \\
(\mathbf{t} / \mathbf{h a})\end{array}$ & $\begin{array}{c}\mathbf{S Y} \\
(\mathbf{t} / \mathbf{h a})\end{array}$ & $\begin{array}{c}\text { AGY } \\
(\mathbf{t} / \mathbf{h a})\end{array}$ & $\begin{array}{c}\text { ASY } \\
(\mathbf{t} / \mathbf{h a})\end{array}$ & $\begin{array}{c}\text { TVC } \\
(\mathbf{B i r r} / \mathbf{h a})\end{array}$ & $\begin{array}{c}\text { GB } \\
(\mathbf{B i r r} / \mathbf{h a})\end{array}$ & $\begin{array}{c}\text { NB } \\
\left(\mathbf{B i r r}_{\mathbf{h a}} \mathbf{-}^{\mathbf{1}}\right)\end{array}$ \\
\hline $\mathbf{1}$ & 15 & 40 & 2.9043 & 4.7247 & 2613.87 & 4252.23 & 2140 & 40389.921 & 38249.921 \\
\hline $\mathbf{2}$ & 15 & 60 & 3.0649 & 5.3416 & 2758.41 & 4807.44 & 2410 & 43007.463 & 40597.463 \\
\hline $\mathbf{3}$ & 15 & 80 & 3.3315 & 6.0545 & 2998.35 & 5449.05 & 2680 & 47016.585 & 44336.585 \\
\hline $\mathbf{4}$ & 15 & 100 & 3.2075 & 5.7321 & 2886.75 & 5158.89 & 2950 & 45161.793 & 42211.793 \\
\hline $\mathbf{5}$ & 15 & 120 & 3.0654 & 5.5386 & 2758.86 & 4984.74 & 3220 & 43226.298 & 40006.298 \\
\hline $\mathbf{6}$ & 15 & 140 & 3.3482 & 5.4599 & 3013.38 & 4913.91 & 3490 & 46577.322 & 43087.322 \\
\hline $\mathbf{7}$ & 15 & 160 & 2.9523 & 5.9445 & 2657.07 & 5350.05 & 3760 & 42290.505 & 38530.505 \\
\hline $\mathbf{8}$ & 20 & 40 & 2.8268 & 4.6429 & 2544.12 & 4178.61 & 1740 & 39359.952 & 37619.952 \\
\hline $\mathbf{9}$ & 20 & 60 & 3.1543 & 5.6952 & 2838.87 & 5125.68 & 2010 & 44475.561 & 42465.561 \\
\hline $\mathbf{1 0}$ & 20 & 80 & 3.0582 & 5.6579 & 2752.38 & 5092.11 & 2280 & 43267.662 & 40987.662 \\
\hline $\mathbf{1 1}$ & 20 & 100 & 3.7705 & 7.149 & 3393.45 & 6434.1 & 2550 & 53532.495 & 50982.495 \\
\hline $\mathbf{1 2}$ & 20 & 120 & 3.1371 & 5.9444 & 2823.39 & 5349.96 & 2820 & 44535.717 & 41715.717 \\
\hline
\end{tabular}


Effect of Seed Rate and Row Spacing on Yield and Yield Components of Rain Fed Lowland Rice (Oryzasativa L.) Variety

\begin{tabular}{|l|c|c|c|c|c|c|c|c|c|}
\hline $\mathbf{1 3}$ & 20 & 140 & 3.2904 & 6.1108 & 2961.36 & 5499.72 & 3090 & 46578.024 & 43488.024 \\
\hline $\mathbf{1 4}$ & 20 & 160 & 3.3703 & 5.8417 & 3033.27 & 5257.53 & 3360 & 47258.181 & 43898.181 \\
\hline $\mathbf{1 5}$ & 25 & 40 & 2.9374 & 4.7961 & 2643.66 & 4316.49 & 1540 & 40869.198 & 39329.198 \\
\hline $\mathbf{1 6}$ & 25 & 60 & 2.8782 & 4.9622 & 2590.38 & 4465.98 & 1810 & 40329.306 & 38519.306 \\
\hline $\mathbf{1 7}$ & 25 & 80 & 3.5205 & 5.7009 & 3168.45 & 5130.81 & 2080 & 48931.047 & 46851.047 \\
\hline $\mathbf{1 8}$ & 25 & 100 & 3.6355 & 6.7918 & 3271.95 & 6112.62 & 2350 & 51506.469 & 49156.469 \\
\hline $\mathbf{1 9}$ & 25 & 120 & 3.5464 & 6.3497 & 3191.76 & 5714.73 & 2620 & 49946.436 & 47326.436 \\
\hline $\mathbf{2 0}$ & 25 & 140 & 3.2242 & 5.7718 & 2901.78 & 5194.62 & 2890 & 45407.574 & 42517.574 \\
\hline $\mathbf{2 1}$ & 25 & 160 & 3.478 & 6.3302 & 3130.2 & 5697.18 & 3160 & 49094.316 & 45934.316 \\
\hline $\mathbf{2 2}$ & 30 & 40 & 2.8935 & 4.841 & 2604.15 & 4356.9 & 1440 & 40384.305 & 38944.305 \\
\hline $\mathbf{2 3}$ & 30 & 60 & 3.3033 & 5.7171 & 2972.97 & 5145.39 & 1710 & 46309.563 & 44599.563 \\
\hline $\mathbf{2 4}$ & 30 & 80 & 3.1283 & 5.8584 & 2815.47 & 5272.56 & 1980 & 44335.917 & 42355.917 \\
\hline $\mathbf{2 5}$ & 30 & 100 & 3.1977 & 6.3903 & 2877.93 & 5751.27 & 2250 & 45753.579 & 43503.579 \\
\hline $\mathbf{2 6}$ & 30 & 120 & 3.2589 & 5.7451 & 2933.01 & 5170.59 & 2520 & 45800.343 & 43280.343 \\
\hline $\mathbf{2 7}$ & 30 & 140 & 3.1011 & 5.1464 & 2790.99 & 4631.76 & 2790 & 43236.477 & 40446.477 \\
\hline $\mathbf{2 8}$ & 30 & 160 & 3.4444 & 5.7386 & 3099.96 & 5164.74 & 3060 & 48047.148 & 44987.148 \\
\hline
\end{tabular}

$R S=$ Row spacing $(\mathrm{cm}) ; S R=$ seed rate $\left(\mathrm{kg} \mathrm{ha}^{-1}\right) ; T V C=$ Total variable cost $\left(\right.$ Birr $\left.\mathrm{ha}^{-1}\right) \mathrm{GY}$, Average grain yield

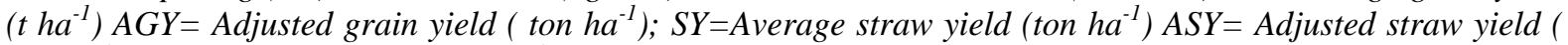
ton $\left.\mathrm{ha}^{-1}\right) ; G B=$ Gross benefit $\left(\right.$ Birr ha $\left.{ }^{-1}\right) ; N B=\operatorname{Net}$ benefit $\left(B i r r ~ h a^{-1}\right)$

Table5. Dominance analysis for seed rate by row spacing interaction for grain yield of low land rice at Fogera

\begin{tabular}{|c|c|c|c|c|c|}
\hline Treatments & $\mathbf{R S}$ & SR & TVC(B ha-1) & NB & Dominance \\
\hline 22 & 30 & 40 & 1440 & 38944.3 & \\
\hline 15 & 25 & 40 & 1540 & 39329.2 & \\
\hline 23 & 30 & 60 & 1710 & 44599.6 & \\
\hline 8 & 20 & 40 & 1740 & 37620.0 & D \\
\hline 16 & 25 & 60 & 1810 & 38519.3 & D \\
\hline 24 & 30 & 80 & 1980 & 42355.9 & D \\
\hline 9 & 20 & 60 & 2010 & 42465.6 & D \\
\hline 17 & 25 & 80 & 2080 & 46851.0 & \\
\hline 1 & 15 & 40 & 2140 & 38249.9 & D \\
\hline 25 & 30 & 100 & 2250 & 43503.6 & D \\
\hline 10 & 20 & 80 & 2280 & 40987.7 & D \\
\hline 18 & 25 & 100 & 2350 & 49156.5 & \\
\hline 2 & 15 & 60 & 2410 & 40597.5 & D \\
\hline 26 & 30 & 120 & 2520 & 43280.3 & D \\
\hline 11 & 20 & 100 & 2550 & 50982.5 & \\
\hline 19 & 25 & 120 & 2620 & 47326.4 & $\mathbf{D}$ \\
\hline 3 & 15 & 80 & 2680 & 44336.6 & $\mathbf{D}$ \\
\hline 27 & 30 & 140 & 2790 & 40446.5 & D \\
\hline 12 & 20 & 120 & 2820 & 41715.7 & D \\
\hline 20 & 25 & 140 & 2890 & 42517.6 & D \\
\hline 4 & 15 & 100 & 2950 & 42211.8 & D \\
\hline 28 & 30 & 160 & 3060 & 44987.1 & D \\
\hline 13 & 20 & 140 & 3090 & 43488.0 & D \\
\hline 21 & 25 & 160 & 3160 & 45934.3 & D \\
\hline 5 & 15 & 120 & 3220 & 40006.3 & D \\
\hline 14 & 20 & 160 & 3360 & 43898.2 & D \\
\hline 6 & 15 & 140 & 3490 & 43087.3 & D \\
\hline 7 & 15 & 160 & 3760 & 38530.5 & D \\
\hline
\end{tabular}

$R S=$ Row spacing $(\mathrm{cm}) ; S R=$ seed rate $\left(\mathrm{kg} \mathrm{ha}^{-1}\right) ; T V C=$ Total variable cost $\left(\right.$ Birr ha $\left.{ }^{-1}\right) ; N B=$ Net benefit $\left(\right.$ Birr ha $\left.{ }^{-1}\right)$

Table6. MRR analysis for seed rate by row spacing interaction for grain yield of low land rice at Fogera

\begin{tabular}{|c|c|c|c|c|c|}
\hline Treatments & RS & SR & TVC (Birr/ha) & NB Birr ha-1 & MRR (\%) \\
\hline $\mathbf{2 2}$ & 30 & 40 & 1440 & 38944.3 & 384.893 \\
\hline $\mathbf{1 5}$ & 25 & 40 & 1540 & 39329.2 & 3100.2147 \\
\hline $\mathbf{2 3}$ & 30 & 60 & 1710 & 44599.6 & 608.50919 \\
\hline $\mathbf{1 7}$ & 25 & 80 & 2080 & 46851.0 & \\
\hline
\end{tabular}


Effect of Seed Rate and Row Spacing on Yield and Yield Components of Rain Fed Lowland Rice (Oryzasativa L.) Variety

\begin{tabular}{|c|c|c|c|c|c|}
\hline $\mathbf{1 8}$ & 25 & 100 & 2350 & 49156.5 & 853.86 \\
\hline $\mathbf{1 1}$ & $\mathbf{2 0}$ & $\mathbf{1 0 0}$ & $\mathbf{2 5 5 0}$ & $\mathbf{5 0 9 8 2 . 5}$ & $\mathbf{9 1 3 . 0 1 3}$ \\
\hline
\end{tabular}

$R S=$ Row spacing $(\mathrm{cm}) ; \mathrm{SR}=$ Seed rate $\left(\mathrm{kg} \mathrm{ha}^{-1}\right) ; T V C=$ Total variable cost $\left(\right.$ Birr ha $\left.\mathrm{h}^{-1}\right) ; \mathrm{NB}=$ Net benefit $($ Birr $\left.\mathrm{ha}^{-}{ }^{\mathrm{l}}\right) ; M R R \%=$ Marginal rate of return in percent

\section{REFERENCES}

[1] Africa Rice Center (Africa rice) (2010). Improving Access to Rice Seed and Building a Rice Data System for Sub-Saharan Africa (Japan Emergency Project). Final Report of the Japan Emergency Project, Cotonou, Benin.

[2] Alen, M.S., Baki, M.A., Sultana, M.S., Ali, KJ. and Islam, M.S. 2012. Effect of variety, spacing and number of seedlings per hill on the yield potentials of transplant Aman rice. International Journal of Agronomy and Agricultural Research, 2(12): 10-15.

[3] Asch, F. and Brueck H. 2010.Rice Crop Innovations and Natural-Resource Management: A Glimpse into the Future Presented at 2nd Africa Rice Congress: Innovations and Partnerships to Realize Africa Rice Potential, March 22-26. Mali: Bamako.

[4] Balock, A. W., A. M. Soomro, M. A. Javed, M. Ahimed, H. R. Bughio, M. S. Bughio and N. N. Mastoi (2002). Optimum plant density for high yield in rice (Oryza sativa L.).Asian Journal of Plant Sciences. 1(1): 25-27.

[5] Carrijo, D.R., Lundy, M.E., Linquist, B.A. (2017). Rice yields and water use under alternate wetting and drying irrigation: a meta-analysis. Field Crops Res. 203, 173-180.

[6] CIMMYT (1988). From Agronomic Datato Farmer Recommendations: An Economics Training Manual. Completely revised edition, Mexico, DF.

[7] CSA (Central Statistical Agency). 2012. Federal democratic republic of Ethiopia. Statistical Abstracts, Addis Ababa: Ethiopia.

[8] Gafaar, N A. (2007).Response of some bread wheat varieties grown under different levels of planting density and nitrogen fertilizer. Minufiya Journal of Agriculture, 32: 165-183.

[9] Haque D. (2002).Effect of Madagascar Technique of Younger Seedling and Wider Spacing on Growth and Yield of Boro rice.MS Thesis, Dept. Agron., Bangladesh Agril. Univ., Mymensingh;

[10] Hegde, S. and V. Hegde (2013).Assessment of Global Rice Production and Export Opportunity for Economic Development in Ethiopia. International Journal of Science and Research (IJSR), $\quad 2$ 2(6): $\quad 2319-$ 7064.

[11] Khush, G.S. (2005). What it will take to feed 5.0 billion rice consumers in 2030. Plant Mol. Biol. 59, 1-6.

[12] Marschner, H. (1995). Mineral nutrition of higher plants. $2^{\text {nd }}$ Ed. Academic Press, London. 783p.

[13] MoARD (2005).Ministry of Agriculture and Rural Development, Crop Variety Register, , Crop Development Department, Addis Ababa, Ethiopia.

[14] MOARD (2010). Ministry of Agriculture and Rural Development, Crop Variety Register, Crop Development Department, Addis Ababa, Ethiopia: 48.

[15] Mohaddesi, A., Abbasian, A., Bakhshipour, S. and Aminpanah, H. 2011. Effect of different levels of nitrogen and plant spacing on yield, yield components and physiological dices in high yield rice. Amer-Eur Journal of Agriculture and Environment, 10: 893-900.

[16] Mosalem, M. E., M. Zahran, M. M. El-Menofi and A. M. Moussa (2002).Effect of sowing methods and seeding rates on growth and yield of some wheat cultivars, pp. 239-392. In: Proceedings of The 5th International Triticale Symposium, June 30-July 5, Radizikow, Poland.

[17] NRRDSE, (2009) National Rice Research and Development Strategy of Ethiopia; Ministry Of Agriculture and Rural Development, Addis Ababa, Ethiopia.

[18] SAS (Statistical Analysis Software) Institute Inc. 2009.SAS/GRAPH 9.2: Reference, Fourth Edition. Cary, NC: SAS Institute Inc.

[19] Seleiman, M.F., Ibrahim, M.E., Abdel-Aal, S.M. and G.A. Zahran (2010).Effect of seeding rates on productivity, technological and rheological characteristics of bread wheat (triticumaestivumL.).International Journal of Current Research.4: 075-80??.

[20] SewunetAshebir (2005). Effect of Nitrogen and Seeding Rates on Grain Yield, Yield Components and Nitrogen Uptake of Rainfed Rice (OryzasativaL) in Fogera, South Gonder. M. Sc. Thesis, Alemaya University.

[21] Sultana M, Rahaman M, and M. Rahman (2012).Effect of row and hill spacing on the yield performance of Boro rice (cv. BRRI dhan45) under aerobic system of cultivation. Journal of the Bangladesh Agricultural University, .10(1): 39-42. 
[22] Sultana, M.R., Rahman, M.M. and Rahman, M.H. 2012.Effect of row and hill spacing on theyield performance of boro rice (cv. BRRI dhan45) under aerobic system of cultivation. Bangladesh Journal of Bangladesh Agricultural University, 10(1): 39-42.

[23] Tilahun Tadesse, MinaleLiben, AlemayehuAssefa, BelestiYeshalem and Tesfaye Wossen, 2007. Effect of nitrogen and phosphorus fertilizers on the yield of rice in Fogera and Metema areas. In: Ermiase A., Akalu T., Alemayehu A., Melaku W., Tadesse D., and Tilahun T. (eds.). Proceedings of the 1st Annual Regional Conference on Completed Crop Research Activities, 14- 17 August 2006. Amhara Regional Agricultural Research Institute, Bahir -Dar, Ethiopia.

[24] Yamada, N. (1961).On the relationship between yield and spacing in rice. Agricultural and Horticultural.36 (1): 13-18.

[25] Yoshida, S. 1981. Fundamental of rice crop science. Institutional Rice Research Institute, Manila, Philippines: 269pp.

[26] Zeng, L. and M. C. Shannon (2000).Effects of Salinity on grain yield and yield components of rice at different seeding densities. Agronomy Journal; 92: 418-423.

[27] ZewdieBishaw, Paul C. Struik and A.J.G. Van Gastel. (2014). Assessment of on-farm diversity of wheat varieties and landraces: evidence from farmer's field in Ethiopia. African Journal of Agricultural Research, 9 (38): 2948-2963.

Citation: Zelalem Tadesse, et.al, "Effect of Seed Rate and Row Spacing on Yield and Yield Components of Rain Fed Lowland Rice (Oryzasativa L.) Variety” International Journal of Research Studies in Agricultural Sciences (IJRSAS), 2019; 5(12), pp. 18-26, http://dx.doi.org/10.20431/2454-6224.0512003

Copyright: (C) 2019 Authors. This is an open-access article distributed under the terms of the Creative Commons Attribution License, which permits unrestricted use, distribution, and reproduction in any medium, provided the original author and source are credited. 